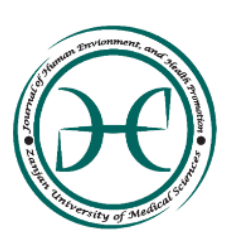

Journal of Human, Environment and Health Promotion

Journal homepage: www.zums.ac.ir/jhehp

\title{
Safety Assessment of Zanjan Drinking Water System Using Water Safety Plan
}

\author{
Akbar Eslami a, Mohtasham Ghafari a, Valiallah Sohbatloo ${ }^{\text {a,* }}$, Farzane Fanaei a \\ ${ }^{a}$ Department of Environmental Health Engineering School of Public Health, Shahid Beheshti University of \\ Medical Sciences, Tehran, Iran.
}

*Corresponding author. E-mail address: vsohbatloo@yahoo.com

\section{A R T I C L E I N F O}

Article history:

Received April 22, 2017

Accepted May 30, 2017

Article Type:

Original Article

Keywords:

Drinking Water

Water Safety Plan

Risk Management

Risk Factor

Zanjan

\begin{abstract}
A B S T R A C T
Background: The best way to assure the quality of drinking water is implementing a comprehensive and integrated management system with cooperation of all the related organizations Therefore, the purpose of this study is the assessment of safety in drinking water supply system of Zanjan.

Methods: This investigation was performed by WSP-QA Tool software and WHO and IWA manual of water safety plan on water supply of Zanjan city in 2016. For this purpose, software checklist (containing 85 questions) were provided and completed according to the history of Zanjan Water and Wastewater Company and interviewing the experts of this company.

Results: Data indicated that from all phases investigated, 52.95\% was adjusted with WSP. System Description with the highest score, showed highest percentage of adjustment with the water safety plan $(100 \%)$ and the phase related to verification and control with the lowest score, showed lowest percentage of adjustment with the water safety plan. Conclusion: Meanwhile, water distribution system is provided with a relatively average safety level and there is the potential of various pollutions caused by identified risks in water distribution system, therefore changing the present approach is suggested.
\end{abstract}

\section{Introduction}

Water suppliers are in charge of providing the healthy and safe water for the society which consumes it. One of the most important concerns in this field, is the subject of public health and hygiene. Water suppliers have to be a9ware of all the risks existing in this field and they have to apply the risk management strategies at the right time [1]. Epidemic diseases caused by the unhealthy water resource, have influenced all the countries such as developed and developing countries and led to mortality and economic damages to individual and/or society. One of the most important issues which has occurred in developed countries is related to the spread of cryptosporidiosis in 1993 at Milwaukee in Canada.

The investigations of the causes of the spread of this disease have clarified that deficiencies in designing and operations of water treatment had led to this incident [2].

To cite: Eslami A, Ghafari M, Sohbatloo V, Fanaei F. Safety Assessment of Zanjan Drinking Water System Using Water Safety Plan. J Hum Environ Health Promot. 2017; 2(3):138-146. 
The most effective way for assuring the safety of a drinking water supply system is using the strategy of comprehensive risk assessment and management in a way which contains all the phases of water supply from the catchment area to the consumption point. These kinds of strategies are called the water safety plan [3].

The water Safety Plan (WSP) contains actions which can prevent or reduce water pollution during various stages of supplying water [4]. To assess the implementation of the water safety plan stages, World Health Organization (WHO) and International Water Association (IWA) presented a software, entitled WSP - QA TOOL, in 2010.

This software is a tool which identifies the weakness and strength of implementing every stage of water safety plan, so that resulted advantages of implementing WSP can be confirmed [5]. According to mentioned subjects above, supplying healthy water is only possible through preventive and comprehensive management which is stated in drinking Water Safety Plan, by organizations, especially WHO.

Therefore, the purpose of this study is the assessment of drinking water supply safety in Zanjan city according to water safety plan of WHO. WSPs introduce the probable deficiencies and by means of system development or promoting the controlling actions related to risks detection provide the most appropriate way to control the problem [6]. Considering the position and its connection with the surrounding environment and the potential of pollution related to this connection, and the consequent threat for the consumers' health, water supply system seeks specific control and because of that it has been under attention of authorities and researchers [7].

According to the study of Aghaei (2014) which was about the assessment of water supply of Ardabil city by means of water safety plan of WHO, 21\% was adjusted with WSP in which, System Description showed the highest percentage of coordination $(62.5 \%)$ and Management Procedure showed the lowest percentage of coordination with WSP (11.11\%) [8]. According to Fanaee et al. (2015) study on assessment of water supply system of Birjand city by means of
WSP of WHO based on risk management approach in 2015, from total score of 440 of complete implementation of the plan and total score of 328 related to the studied phases, the final score of 190 was achieved and $43 \%$ was adjusted with WSP in which System Description with highest score (7 out of 8 ) showed the highest percentage of coordination with WSP $(87.5 \%)$ and Management Procedure with the lowest score (9 out of 36), showed the lowest percentage of coordination with WSP (25\%)[9].

Ezenwaji et al. (2014) who studied the application of WSP as a tool for enhancing quality of drinking water in Nigeria. Reducing the water pollution in resource to its minimum, reducing or omitting the pollutants during refinement processes and preventing pollution during storage, and water transfer and distribution are the mentioned advantages in their study [10]. In 2005, 10 countries of Latin America emphasized on implementing WSP based on WHO, consequently PAHO (Pan American Health Organization), CDC (Centers for disease Control and prevention) and EPA implemented the WSP in Jamaica [11]. Sopak (2010) estimated the benefit-cost ratio of implementing WSP in the Koror-Airari island in Palau republic as 5.9 [12].

\section{Materials and Methods}

\subsection{The Study site characteristics}

Zanjan is is a province, the center of which is limited from north to east Azerbaijan province, from north-east to Tarem County, from east to Soltaniye County, from west to Mahneshan County and from south to Ijroud County.

The population of this city is 486495 people [13].

The most important flowing river in this region is Zanjan Rood [14]. Zanjan city has a cold semiarid climate - according to the Martonne - and its height is 1659 meters [15]. Water supplies for drinking and agriculture of the region are formed by superficial and underground waters. The water needed for Zanjan citizens is now supplied from 23 wellbores situated in residential region (center and west of the city), 15 wellbores of east and also 
18 wellbores of Bonab (65\% of underground water) and Taham dam $(35 \%$ superficial water)[16].

\subsection{Study type}

This is a cross-sectional descriptive analytic study which was done on drinking water supply system of Zanjan city of Zanjan province in 2016.

The software which is used in this study is based on Excel software provided from WHO and IWA in 2010. Since the software is new, it is not applied in qualitative management of drinking water in different countries of the world, even in countries which have the applied WSP. The major advantage of the application of this software for assessment of WSP by water suppliers is the identification of the fields which needs development and opportunities which can be enhanced. Another feature of this software is the application of it as a manual in a place which WSP has not implanted totally or is at first stages of implementation. In this study, the latter feature is applied [17].

In the second part of the study, books, references and various research articles were investigated and the most current risks in water supply system and also the probable specific risks which can occur in the process of water supply were detected. Then, experts of water supply (water resources, treatment and distribution), health and environment specialists from the organization or out of the organization were chosen. Efforts were made to choose the experienced and expert staff who were aware of water resources, treatment, distribution of water, and the risks which can influence water safety of water supply system from the catchment area to the consumption point. The staff should have the ability of detection and management of associated risks.

The common detected risks associated with the compartments of water supply system involved 4 stages:

- Detected risks of the source

- Detected risks of the treatment

- Detected risks of water distribution network and reservoir sources

- Detected risks of consumption point
For this purpose, 10 members of the staff were chosen and they were asked to detect the risks in each phase and classify and prioritize them according to the importance of the risk in water supply system of Zanjan city. For assessment of each risk, the risk score of 1 allocated to the least important risk (lowest priority) and 10 (or more depending on number of risks detected in each phase) allocated to the most important risk (highest priority) according to counseling with the experts of drinking water supply of Zanjan city.

Total number of questions asked about the risks from the experts were 56. 17 questions were about the water source, 15 questions were about the refinery, 13 questions were about the distribution network and storage source and finally 11 questions were about the consumption point. In this study, risk scoring matrix of $5 \times 5$ of chapter 4 which exists at the third version of the WHO book was applied.

In this study, for the reliability of the designed questionnaire, completion of the questionnaire was done two times with one- week interval by the experts to check the certainty of the given responses. For this purpose, the reliability test of the asked questions were done in two interviews with the experts and by means of Pearson Correlation Coefficient by SPSS software (version 23). In this study, the resulted correlation coefficient of 5 questions from two tests, were lower than the accepted limit $(<0.6)$ therefore they were omitted from the questionnaire and eventually the reliability of 51 questions were confirmed.

\section{Results and Discussion}

After collecting the data from the checklists, analysis was done by WSP QA TOOL in Excel software. The below diagram shows the results of the assessment of the general amount of implementing all the phases of the WSP. The mentioned diagram is shown as its software format in Fig. 1. In the final part of the software, the assessment results after analysis of the data will be given in graphs and tables. These summarized diagrams and tables would assist the water supplier in assessment of his general function. 
According to the responses of the group members of the group (experts of water supply system and health organization of the Zanjan city) the most dangerous risks for each four compartments of water supply system (water resources, treatment, distribution network and storage source, and consumption point) were detected and reforming actions were suggested. Results of each four phases are reported in tables 1 to 4 .

Since the risk assessment of phases of implementing the water safety plan by software is based on complete implementation of water supply system management plan and because WSP is not fully implemented in Zanjan city, questions and scores of phases which couldn't be evaluated were not considered in the final analysis.

Data showed that from the total score of 440 complete implementation of the plan and total score of 352 of investigated phases, score of 233 was achieved and $52.95 \%$ was coordinated with WSP in which system description phase with the highest score ( 8 out of 8 ) represented the highest percentage of coordination with WSP (100\%).

The phase of reviewing the WSP with the least score (16 out of 56), represented the lowest percentage of coordination with the WSP (28.57\%). Following the resulted advancements with the application of WSP in South Korea in 2013, the risk detection and the assessment has been defined as the the key parameters in WSP. These parameters in Fanaee's study conducted in Birjand city in 2015 was $52 \%$, based on Birjand's geographical and its climate status. In the present study, according to the table 4 of the software output, this phase has scored 79 out of 100 which represents $79 \%$ of the implementation advancement synchronized with WSP. The weak points or the vulnerability of the system is evident in these diagrams, in a way that the operational concentration of the supplier organization is on the system's description and the management procedures and the lower concentration is on the other phases which reveals the major deficiency of the present approach on the management of the quality of the drinking water in Zanjan city.

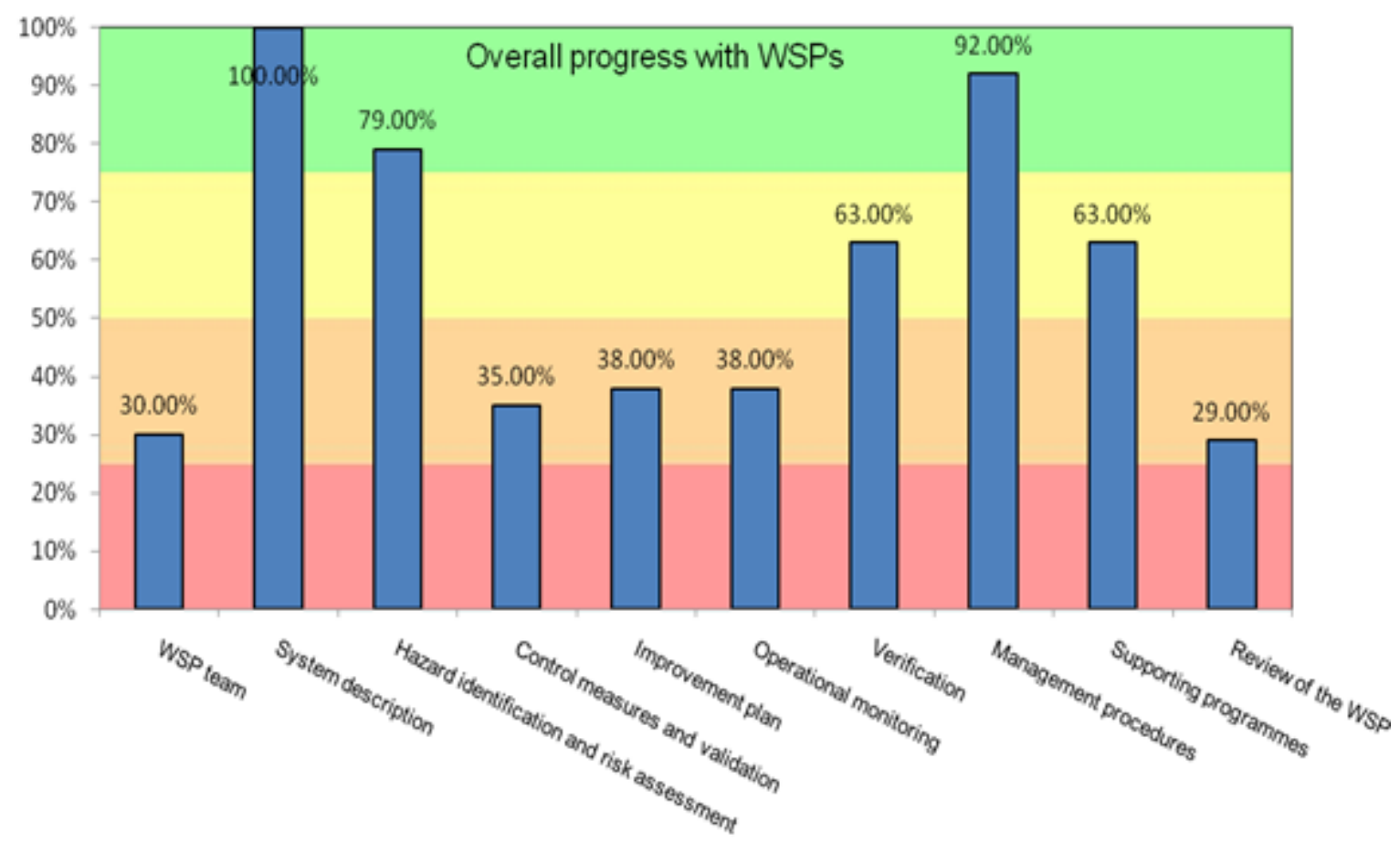

Fig. 1: Total results of the amount of implementing WSP in water supply system of Zanjan. 
Table 1: Risk analysis - assessment of most important risks in the catchment area in Zanjan city.

\begin{tabular}{|c|c|c|c|c|c|c|c|c|}
\hline \multirow{2}{*}{ Risk } & \multirow{2}{*}{ Risky incident } & \multicolumn{3}{|c|}{ Risk assessment } & \multirow[b]{2}{*}{ Reforming actions } & \multicolumn{3}{|c|}{$\begin{array}{c}\text { Risk reassessment after reforming } \\
\text { actions }\end{array}$} \\
\hline & & possibility & intensity & risk & & possibility & intensity & risk \\
\hline Chemical & $\begin{array}{l}\text { High } \\
\text { concentration of } \\
\text { nitrite and } \\
\text { nitrate }\end{array}$ & 3 & 4 & 12 & $\begin{array}{l}\text { 1. The Removal of polluted wells } \\
\text { from consumption cycle and } \\
\text { replacing them with better } \\
\text { sources. 2. Speeding up the } \\
\text { collection of wastewater. } 3 \text {. Using } \\
\text { supporting pipes for waste water } \\
\text { exclusion wells. 4. Combination } \\
\text { of high nitrate water with sources } \\
\text { of low nitrate in water storage } \\
\text { source reduces the nitrate } \\
\text { concentration of water. }\end{array}$ & 2 & 2 & 4 \\
\hline Chemical & $\begin{array}{l}\text { Microbial } \\
\text { pollution, } \\
\text { pesticides and } \\
\text { fertilizers } \\
\text { resulted from } \\
\text { agricultural } \\
\text { actions in } \\
\text { catchment area }\end{array}$ & 4 & 4 & 16 & $\begin{array}{l}\text { 1. Using organic fertilizers and } \\
\text { reducing water pollution. } 2 . \\
\text { Combined management of pests } \\
\text { and reducing water pollution. } 3 \text {. } \\
\text { Aerial spraying control especially } \\
\text { in regions near to wells and } \\
\text { catchment area of Taham Dam. } 4 . \\
\text { Encouragement and providing } \\
\text { facilities for biologic fight instead } \\
\text { of chemical approaches against } \\
\text { pests. }\end{array}$ & 2 & 3 & 6 \\
\hline Chemical & $\begin{array}{l}\text { Pollution } \\
\text { resulted from } \\
\text { application of } \\
\text { poisons and } \\
\text { algal flourishing } \\
\text { in catchment } \\
\text { area }\end{array}$ & 4 & 3 & 12 & $\begin{array}{l}\text { 1. Limitation in usage of nitrogen } \\
\text { and phosphorus as controlling } \\
\text { agents of growth and algal } \\
\text { flourishing. 2. Prevention of } \\
\text { accession of homemade and } \\
\text { industrial wastewater to } \\
\text { catchment area. 3. Using gybsum } \\
\text { and aluminum for protection of } \\
\text { algae in small rivers. } 4 \text {. Using the } \\
\text { algicides for water used for } \\
\text { agriculture before algal growth. }\end{array}$ & 2 & 2 & 4 \\
\hline Physical & $\begin{array}{l}\text { Floods resulted } \\
\text { from seasonal } \\
\text { rainfall, and } \\
\text { quality and } \\
\text { quantity change } \\
\text { of water source }\end{array}$ & 4 & 3 & 12 & $\begin{array}{l}\text { 1. Watershed and flood control in } \\
\text { catchment area. } 2 \text {. Deviations of } \\
\text { local floods. } 3 \text {. Using the stored } \\
\text { water as the entering water to } \\
\text { refinery, at the time of heavy } \\
\text { rainfall. } 4 \text {. Proper storage time of } \\
\text { water in dam or source. }\end{array}$ & 2 & 2 & 4 \\
\hline Chemical & $\begin{array}{l}\text { Corrosion or } \\
\text { deficiency of } \\
\text { the pipe of well } \\
\text { wall }\end{array}$ & 3 & 3 & 9 & $\begin{array}{l}\text { 1. Using of lattice in the well wall } \\
\text { pipe. } 2 \text {. Installing filters in wells. } \\
\text { 3. Pouring the gravels around the } \\
\text { well wall pipe. } 4 . \text { The Cross } \\
\text { section of pipe should be V- } \\
\text { shaped. }\end{array}$ & 2 & 1 & 2 \\
\hline
\end{tabular}


Table 2: The Risk analysis - assessment of the most important risks in water treatment of Zanjan city.

\begin{tabular}{|c|c|c|c|c|c|c|c|c|}
\hline \multirow[b]{2}{*}{ Risk } & \multirow[b]{2}{*}{ Risky incident } & \multicolumn{3}{|c|}{ Risk assessment } & \multirow[t]{2}{*}{ Reforming actions } & \multicolumn{3}{|c|}{$\begin{array}{l}\text { Risk reassessment after } \\
\text { reforming actions }\end{array}$} \\
\hline & & possibility & intensity & risk & & possibility & intensity & risk \\
\hline $\begin{array}{l}\text { Physical, } \\
\text { Chemical }\end{array}$ & $\begin{array}{l}\text { Problems } \\
\text { associated with } \\
\text { inappropriate } \\
\text { function of filters } \\
\text { (obstruction, } \\
\text { inadequate } \\
\text { removal of } \\
\text { particles, high } \\
\text { opacity in output } \\
\text { and etc.) }\end{array}$ & 4 & 4 & 12 & $\begin{array}{l}\text { 1. Adjusting the water and air current } \\
\text { during bed washing. } 2 \text {. Control of the } \\
\text { amount of injected chemical } \\
\text { substance. } 3 \text {. Speed gradient } \\
\text { adjustment and the amount of } \\
\text { loading. } 4 \text {. Keeping up the remaining } \\
\text { chlorine in input water of filters. }\end{array}$ & 2 & 2 & 4 \\
\hline $\begin{array}{l}\text { Microbial, } \\
\text { physical, } \\
\text { Chemical }\end{array}$ & $\begin{array}{l}\text { Deficiency in } \\
\text { invert washing } \\
\text { system of filters }\end{array}$ & 3 & 4 & 12 & $\begin{array}{l}\text { 1. Enough resting of filter before } \\
\text { going back to the exploitation system. } \\
2 \text {. Proper selection of coagulator or } \\
\text { the added polymer to the washing } \\
\text { water. } 3 \text {. Operator has to consider the } \\
\text { water temperature in choosing } \\
\text { washing rate. Intensity and the time } \\
\text { needed for optimal invert washing has } \\
\text { to be considered. } 4 \text {. Choosing the } \\
\text { most optimal expansion status of the } \\
\text { bed between } 20 \text { to } 25 \text { percent for } \\
\text { filter washing. }\end{array}$ & 1 & 2 & 2 \\
\hline Chemical & $\begin{array}{l}\text { Absence of } \\
\text { removal of } \\
\text { organic pollutants } \\
\text { in the process and } \\
\text { risk of } \\
\text { trihalomethanes } \\
\text { formation }\end{array}$ & 4 & 4 & 16 & $\begin{array}{l}\text { 1. Using of disinfectants except free } \\
\text { chlorine. 2. For prevention of } \\
\text { trihalomethanes formation, it is } \\
\text { necessary to reduce the organic } \\
\text { substance of unfiltered water to its } \\
\text { minimum before applying chlorine. } 3 \text {. } \\
\text { Using charcoal beds for the removal } \\
\text { of trihalomethanes. } 4 \text {. Replacement of } \\
\text { using chlorine stages and reducing its } \\
\text { contact to water to its minimum. }\end{array}$ & 2 & 2 & 4 \\
\hline
\end{tabular}

Results of this study showed that according to total implementation of different phases of WSP $(52.95 \%)$ and low attention of water supply organization to some key parameters of WSP and controlling and accreditation in each four major parts of supplying system, especially in distribution network and consumption point, the system is in a moderate safety level and there is the potential of various pollutions resulted from the detected risks in water supply system, therefore reforming the present approach is necessary. However, the high score of some phases such as the system description, management instructions and risk detection and assessment, shows the flexibility of the system to reform the present approach of quality management to WSP.

\section{Conclusion}

In a general view, according to the percentage of general implementation of various phases of WSP in water supply system of Zanjan city $(52.95 \%)$ and low attention of water supply system to some key parameters such as the WSP review, WSP team, and control and accreditation criteria, especially in distribution network and final consumption point, reforming the present approach for more conformity with WSP in which forming a team is one its phases is necessary .

Data resulted from assessment of important risks in this system show that for achieving a desirable drinking water with high quality, removal or reduction of high concentration of nitrite and nitrate in some water sources, matching the refinement processes, and quality preservation 
of drinking water in distribution system by keeping enough chlorine in the network, and reconstruction of infrastructural installations and old pipelines of the city is necessary. According to water safety plans, it is necessary that organizations in the charge participate in accomplishing water safety plans.

Table 3: Risk analysis - assessment of the most important risks of sources and distribution network in Zanjan city.

\begin{tabular}{|c|c|c|c|c|c|c|c|c|}
\hline \multirow{2}{*}{ Risk } & \multirow{2}{*}{ Risky incident } & \multicolumn{3}{|c|}{ Risk assessment } & \multirow[b]{2}{*}{ Reforming actions } & \multicolumn{3}{|c|}{$\begin{array}{l}\text { Risk reassessment after } \\
\text { reforming actions }\end{array}$} \\
\hline & & possibility & intensity & risk & & possibility & intensity & risk \\
\hline $\begin{array}{l}\text { Microbial, } \\
\text { physical }\end{array}$ & $\begin{array}{l}\text { Dysfunction caused } \\
\text { by accidents and } \\
\text { natural disasters }\end{array}$ & 3 & 4 & 12 & $\begin{array}{l}\text { 1. Details of how to contact with key } \\
\text { staff. 2. Clear description of actions } \\
\text { which have to be done at the time of } \\
\text { any incident. } 3 \text {. Related technical and } \\
\text { logistic information. 4. Integrated } \\
\text { and stable management in the } \\
\text { decision making at the moment of } \\
\text { crisis. 5. The exact location of } \\
\text { keeping SOP and equipment. }\end{array}$ & 2 & 1 & 2 \\
\hline $\begin{array}{l}\text { Microbial, } \\
\text { Chemical }\end{array}$ & $\begin{array}{l}\text { Microbial biofilm } \\
\text { formation in storage } \\
\text { sources }\end{array}$ & 3 & 3 & 9 & $\begin{array}{l}\text { 1. Using the disinfectants except free } \\
\text { Chlorine. } 2 \text {. For preventing } \\
\text { formation of trihalomethanes, it is } \\
\text { necessary to reduce the organic } \\
\text { substance of unrefined water to its } \\
\text { minimum before applying the } \\
\text { chlorine. 3. Using of charcoal beds } \\
\text { for elimination of trihalomethanes. } 4 \text {. } \\
\text { Replacement of using chlorine stages } \\
\text { and reducing its contact to water to } \\
\text { its minimum. }\end{array}$ & 2 & 2 & 4 \\
\hline Microbial & $\begin{array}{l}\text { Inadequate } \\
\text { remaining chlorine } \\
\text { in sources and } \\
\text { distribution network }\end{array}$ & 12 & 4 & 9 & $\begin{array}{l}\text { 1. Education of operational staff in } \\
\text { applying chlorine. } 2 \text {. Replacement of } \\
\text { parts of the network in which erosion } \\
\text { and leakage and etc. causes more } \\
\text { consumption of disinfectant. } 3 . \\
\text { Further disinfection through the path } \\
\text { by booster dosing. }\end{array}$ & 2 & 2 & 4 \\
\hline
\end{tabular}


Table 4: Risk analysis - assessment of the most important risks in the consumption point in Zanjan city.

\begin{tabular}{|c|c|c|c|c|c|c|c|c|}
\hline \multirow{2}{*}{ Risk } & \multirow{2}{*}{ Risky incident } & \multicolumn{3}{|c|}{ Risk assessment } & \multirow{2}{*}{ Reforming actions } & \multicolumn{3}{|c|}{$\begin{array}{l}\text { Risk reassessment after } \\
\text { reforming actions }\end{array}$} \\
\hline & & possibility & intensity & risk & & possibility & intensity & risk \\
\hline $\begin{array}{l}\text { Physical, } \\
\text { Microbial }\end{array}$ & $\begin{array}{l}\text { Low awareness of } \\
\text { consumer }\end{array}$ & 4 & 4 & 16 & $\begin{array}{l}\text { 1. Raising awareness between } \\
\text { consumers. 2. Developing the } \\
\text { educational programs for } \\
\text { children and teenagers at } \\
\text { schools and kindergartens, by } \\
\text { presenting correct ways of } \\
\text { consumption management, } \\
\text { beliefs, attitudes, and as a result } \\
\text { the citizens' manner toward } \\
\text { ways of consuming drinking } \\
\text { water has to be changed. } 3 \text {. } \\
\text { Appropriate and honest } \\
\text { informing of consumers. } 4 . \\
\text { Reforming of consumers' life } \\
\text { style. 5. Legal and controlling } \\
\text { actions. }\end{array}$ & 2 & 2 & 4 \\
\hline $\begin{array}{l}\text { Physical, } \\
\text { Microbial }\end{array}$ & $\begin{array}{l}\text { Pollution of home } \\
\text { storage sources }\end{array}$ & 3 & 3 & 9 & $\begin{array}{l}\text { 1. Regular bacteriological tests. } \\
\text { 2. Selecting a specific operator } \\
\text { for residential departments. } 3 \text {. } \\
\text { New rules for proper and } \\
\text { healthy water storage. } 4 . \\
\text { Necessary for the education } \\
\text { awareness of subscribers. } 5 . \\
\text { Temperature and the amount of } \\
\text { remaining chlorine of water } \\
\text { should be regularly checked. }\end{array}$ & 2 & 2 & 4 \\
\hline $\begin{array}{l}\text { Chemical, } \\
\text { Microbial }\end{array}$ & $\begin{array}{l}\text { Corrosions and } \\
\text { metal pollutants } \\
\text { caused by pipes and } \\
\text { connections }\end{array}$ & 3 & 3 & 9 & $\begin{array}{l}\text { 1. Reducing the water corrosion } \\
\text { by neutralizing (buffered } \\
\text { refined water). } 2 \text {. Covering the } \\
\text { lead water supply lines. } 3 \text {. } \\
\text { Replacement of the lead water } \\
\text { supply pipes (with plastic or } \\
\text { cuprous pipes). }\end{array}$ & 2 & 1 & 2 \\
\hline
\end{tabular}

\section{Acknowledgement}

This article was submitted for the master of sciences thesis in the environmental health engineering major of Shahid Beheshti University of Medical Sciences, which is approved in the ethics committee held in March, 2016 with the code of IR.SBMU.PHNS.REC.1394.73. The writers of the article express their gratitude for the respectful experts and water and wastewater organizations of Zanjan for their assistance and cooperation.

\section{References}

1. Swartz CD, Petersoon TJR, Lindhe A. Risk Assessment and Risk Management Water Supply Systems: State- of- the- Art and Case Studies in Southern Africa. 2010.

2. Banjad H, Pirtaj hamedani R, Daneshi N. Strategy Risk Analysis and Critical Control Points of Drinking Water Safety Plan Management. Proceedings of the National Symposium Sustainable Dev Patterns in Water Manag. 2009: 625-639. [In Persian]. 
3. Manshouri M, Shaghaghi Gh. Water Safety Plan Manual Step-by-step Risk Management for Drinking-Water Suppliers. Tehran: Ministry of Health, Treat and Med Training; 2009. [In Persian].

4. Kazemian N. Implementation of Water Safety Program in Water Supply Systems. Tabriz: Sotodeh; 2013: 1-94. [In Persian].

5. WHO and IWA: Water Safety Plan Quality Assurance Tool (user manual); 2010. Available from: URL: https:// www.who.int.

6. Mosaferi M, Rastgoo S. Water Safety Plan: Importance and Effect on Health, Proceedings of the Sixteenth National Conference on Environmental Health. Tabriz Univ Med Sci, Tabriz, Iran. 2013. Available from: URL: https://www.civilica.com/Paper-NCEH16_229. [In Persian].

7. Yazdanbakhsh A, Manshoori M, Fallahzade RA. Risk Assessment for the Control of Critical Points in the Supply of Water from Catchment to Consumer. Proceedings of the 2 th National Conference on Water and Wastewater, Tehran, Iran. 2008. [In Persian].

8. Aghaei M. Assessment of Safety in Drinking Water Supply System of Ardabil City By Using World Health Organization's Water Safety Plan, Based On Risk Management Approach [Dissertation]. Health Faculty: Tehran Univ Med Sci; 2014. [In Persian].

9. Fanaee F. Assessment of Safety in Drinking Water Supply System of Birjand City Using World Health Organization's Water Safety Plan, Based on Risk Management Approach. Tehran, Iran: Shahid Beheshti Uni Med Sci School of Public Health; 2015.

10. Ezenwaji EE, Phil-Eze PO. Water Safety Plan as a Tool for Improved Quality of Municipal Drinking Water in Nigeria. J Environ Prot. 2014; 5(11): 997-1002.
11. PAHO, EPA, CDC. Water Safety Plan [f1] Spanish Town Water Supply St. Catherine, Jamaica. Environ Eng Manag Ltd. 2007.

12. SOPAC: An Economic Assessment of Drinking Water Safety Planning Koror-Airai, Palau; 2010.

13. The Geographical location of Zanjan. Available from: URL: https:// www.TCZ.ir.

14. Abdi P. Editor Zanjan Lead and Zinc Study of environmental pollution plant (Study of Groundwater Resources). National Conference of Operation on Water and Sanitation Sector; Tehran: Agriculture and Natural Resources Research Center of Zanjan. 2008.

15. Zanjan Regional. Available from: URL: https:// www. raziclimate.ir.

16. Studies of Water and Wastewater Company of Zanjan. Department Reported Operating Water and Wastewater Company of Zanjan. 2016. Available from: URL: http://www.mehrnews.com/news/4056548. [In Persian].

17. Gholami M, Boodaghi S, Babaloo E. Assessment of Water Safety Plan in Khoy City Based on Step by Step Risk Management New Approach. 14 ${ }^{\text {th }}$ National Conference on Environ Health, Iran, Yazd. 2011. [In Persian]. 